\title{
Micro-level Estimation of Mercaptoacetic Acid Using its Inhibitory Effect to Mercury Catalyzed Ligand Exchange Reaction of Hexacyanoruthenate(II)
}

\author{
Abhishek Srivastava ${ }^{1, *(D)}$ \\ 1 Department of Chemistry, GLA University, Mathura, U.P. India \\ * Correspondence: aabhichem@gla.ac.in;
}

Scopus Author ID 57191574287

Received: 9.05.2020; Revised: 3.06.2020; Accepted: 3.06.2020; Published: 7.06.2020

\begin{abstract}
The sulfur-containing bioactive molecules (soft base) tends to bind strongly with $\mathrm{Hg}$ (II) (soft acid), thereby inhibiting the mercury (II) catalyzed exchange rate of cyanide ligand from $\left[\mathrm{Ru}(\mathrm{CN})_{6}\right]^{4-}$ by pyrazine. This inhibitory effect of Mercaptoacetic acid (MAA) encourages us to establish a new kinetic method for its micro-level estimation. Optimized reaction condition viz. $6.25 \times 10^{-5} \mathrm{M}\left[\mathrm{Ru}(\mathrm{CN})_{6}{ }^{4-}\right.$ ], $\mathrm{pH}=4.0,7.5 \times 10^{-4} \mathrm{M}$ [Pyrazine], $0.05 \mathrm{M} \mathrm{KCl}, 8.5 \times 10^{-5} \mathrm{M}\left[\mathrm{Hg}^{+2}\right]$ and $45( \pm 0.1){ }^{\circ} \mathrm{C}$ temperature were utilized for the kinetic spectrophotometric investigation at $370 \mathrm{~nm}\left(\lambda \max\right.$ of $\left[\mathrm{Ru}(\mathrm{CN})_{5} \mathrm{Pz}\right]^{3-}$ complex $)$. The modified mechanistic scheme for inhibition caused by sulfur donor ligand, MAA has been proposed. The proposed analytical method provides the detection of MAA up to $2.0 \times 10^{-6} \mathrm{M}$, indicates that the methodology can be effectively and economically employed to analyze the biological samples having MAA. This method can also be convincingly adopted for the quality check of MAA containing industrial products.
\end{abstract}

Keywords: Inhibitory effect; Hexacyanoruthenate(II); Mercaptoacetic acid; Ligand substitution reaction; Michaelis constant; Catalyst inhibitor complex.

(C) 2020 by the authors. This article is an open-access article distributed under the terms and conditions of the Creative Commons Attribution (CC BY) license (https://creativecommons.org/licenses/by/4.0/).

\section{Introduction}

Sulfur is the key element in the living organisms for the various metabolic processes. Sulfur occurs in structural proteins of a cell, in enzymes, and in large numbers of bioactive molecules, which plays a vital role in metabolism [1-4]. Thus there is a continuous demand to develop an effective methodology for the quantitative determination and detection of sulfurbearing compounds in distinct samples. Mercaptoacetic acid (MAA), generally known as thioglycolic acid, is a bi-functional organic compound consisting of carboxyl and thiol groups. The chelating complexes of MAA with metal ions have been used for the determination of $\mathrm{Ag}(\mathrm{I}), \mathrm{Pb}$ (II), Mo(II), $\mathrm{Sn}$ (II), Tl(III) and Fe(III) and extraction of $\mathrm{Cu}$ (II) and $\mathrm{Cd}$ (II) [5-7]. MAA has been widely used in the leather industry for the depilation process, in fabric dying, in cosmetics (mainly in hair perming) [8-9]. The derivatives of MAA are also used as a heat stabilizer for PVC plastics, as a corrosion inhibitor and anti-scaling agent for the oil field industry [10-11]. In contrast to widespread industrial applications, the long term exposure of MAA can cause chronic deceases like cancer and reproductive problems [12]. On acute exposure, MAA causes breathing problems, skin burning, irritation and possible damage of eyes, coughing and choking, gastrointestinal damage, dizziness etc. [13]. American Conference of Governmental Industrial Hygienists (ACGIH) recommended 1 ppm as the airborne exposure 
limit of MMA for an 8-hour work shift. The unavoidable use of MAA and its derivative in various industries and cosmetic products attracts environmental analyst and chemists to develop methods for its micro-level determination.

Numerous reports are available to determine sulfur-bearing compounds in pharmaceutical preparations, biological and analytical samples [14-20]. The determination methods include chromatography [21-24], colorimetry [16] [17], flow injection analysis [25], fluorimetry [26], voltammetry [27-29], potentiometry [30], NMR-spectrometry [31] and spectrophotometry [32-33]. The major disadvantages of most of these methods are a high initial investment and are time-consuming. Very few kinetic reports are available using various detection techniques [34-37]. Naik et al. developed a kinetic spectrophotometric method to quantitatively determine D-Pa utilizing its inhibitory effect towards $\mathrm{Hg}$ (II) catalyzed ligand substitution reaction [38-39].

Ruthenium (a corrosion-resistant material [40]) complexes with several bioactive ligand exhibits widespread applications as Antifungal [41], Antiamebic [42], Anticancer [43], Antimetastatic [44], Immunosuppressant [45], Antileukemic [46-47], Antitumor [48-49] and DNA binder [50-51]. The metal-catalyzed ligand imitation of $\left[\mathrm{Ru}(\mathrm{CN})_{6}\right]^{4-}$ with nitrogen donor heterocyclic ligand in aqueous / surfactant medium have been investigated by several authors [52-53]. The mercury (II) catalyzed imitation of cyanide ligand from $\left[\mathrm{Ru}(\mathrm{CN})_{6}\right]^{4-}$ with pyrazine has been effectively utilized to determine $\mathrm{Hg}$ (II) at trace level [54]. The concept of HSAB (hard-soft acid-base) has been extensively used to explain the stability of different metal complexes. The sulfur-bearing compounds (soft base) exhibit a tendency to bind strongly with $\mathrm{Hg}$ (II) (soft acid) [38-39]. MAA suppresses the mercury(II) catalyzed exchange rate of cyanide ligand from hexacyanoruthenate(II) with pyrazine. This inhibitory effect of MAA encourages us to establish a new kinetic method for its micro-level estimation. The developed method based on ligand imitation reaction between hexacyanoruthenate(II) and pyrazine catalyzed by $\mathrm{Hg}$ (II) is more useful as the uncatalyzed reaction is insignificant under specified reaction condition. The present communication proposes a novel, simple and accurate method which permits to determination MAA down to $2.0 \times 10^{-6} \mathrm{M}$ with good accuracy and reproducibility. This method can also be successfully adopted for the quality check of MAA containing industrial samples.

\section{Materials and Methods}

\subsection{Materials and instrumentation.}

The de-ionized distilled water and analytical grade reagents were used throughout the kinetic measurements. A calculated amount of pyrazine (Merck) and $\mathrm{K}_{4}\left[\mathrm{Ru}(\mathrm{CN})_{6}\right] \cdot 3 \mathrm{H}_{2} \mathrm{O}$ (Merck) were used for the preparation of their stock solutions. Mercaptoacetic acid, procured from Himedia, was used without further purification. All the stock solutions were stored in amber-colored bottles to avoid their possible photo-degradation. $\mathrm{HgCl}_{2}$ solution was prepared daily since the loss in $\left[\mathrm{Hg}^{+2}\right]$ was observed as it gets adsorbed on the glass surface. Hydrochloric acid (S, D. Fine-Chem Ltd. India) and potassium hydrogen phthalate (Merck) were used to prepare a desired buffer solution by the reported method. The ionic strength of the reaction medium was maintained by $\mathrm{KCl}$ (Merck).

The measurement of absorbance at fixed wavelength and acquisition of other kinetic data was carried out on a double beam (Systonic S-926) spectrophotometer fitted with a 
thermo-stated cell compartment. The standard buffer solutions were used to calibrate the digital $\mathrm{pH}$ meter (Toshniwal, CL46) before $\mathrm{pH}$ measurements.

\subsection{Procedure.}

The detailed kinetic investigation of the substitution reaction was utilized to judiciously select the optimum reaction condition at which the indicator reaction is more sensitive and proceed at the fastest rate. All the reacting solutions viz., buffer solution of $\mathrm{pH}=4.0,7.5 \times 10^{-4}$

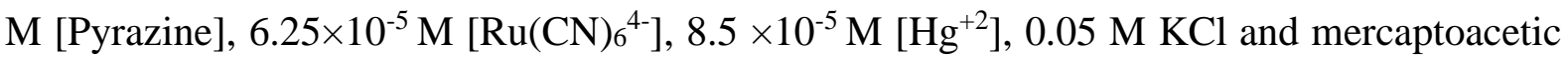
acid were placed in thermostat at $45^{\circ} \mathrm{C}$ to attain thermal equilibrium. Then $2.0 \mathrm{ml}$ from each solution was pipette out and mixed swiftly in the order: buffer solution, pyrazine, $\mathrm{KCl}, \mathrm{HgCl}_{2}$, and mercaptoacetic acid in an Erlenmeyer flask and immersed in the thermostat to fix the same temperature. $2.0 \mathrm{ml}$ of hexacyanoruthenate(II) was finally added to trigger the reaction. After vigorous shaking, the reaction mixture was transferred immediately to the spectrophotometer's cell, kept in a temperature-controlled cell compartment at $45^{\circ} \mathrm{C}$ via circulating water arrangement. The advancement of the indicator reaction was monitored by examining the escalation in absorbance at $370 \mathrm{~nm}$, which corresponds to the stable yellow-colored $\left[\mathrm{Ru}(\mathrm{CN})_{5}\right.$ $\mathrm{Pz}]^{3-}$ complex. To quantitatively determine MAA, a calibration curve was drawn by plotting the change in absorbance as a function of varying [MAA] at fixed time intervals.

\section{Results and Discussion}

The exchange of cyanide ligand with pyrazine from hexacyanoruthenate(II), catalyzed by $\mathrm{Hg}(\mathrm{II})$ produces a yellow-colored $\left[\mathrm{Ru}(\mathrm{CN})_{5} \mathrm{Pz}\right]^{3-}$. The reaction product exhibits a strong absorption band at 370nm due to metal to ligand charge transfer (MLCT) transition. The product absorbs strongly at $370 \mathrm{~nm}$ without any interference from the reactants, catalyst, and other reaction reagents [54].

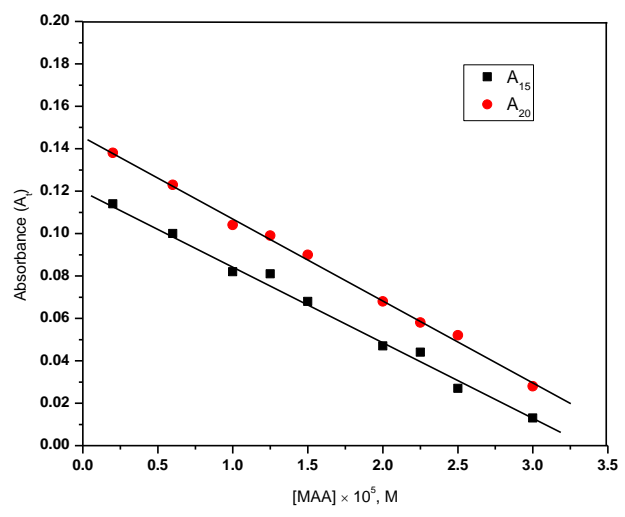

Figure 1. Calibration curve for the Mercaptoacetic acid determination.

The earlier reports on thioglycolic acid and sodium thiosulphate exhibit that the thio compounds inhibit the substitution rate of cyanide with an incoming ligand from hexacyanoruthenate(II) using $\mathrm{Hg}$ (II) as a catalyst [34-36]. Mercaptoacetic acid, a sulfur donor ligand, also decreases the rate of a reaction under investigation by forming a stable catalystinhibitor [Hg(II)----MAA] complex, thereby decreasing the effective concentration of $\mathrm{Hg}$ (II) catalyst resulting in loss of its catalytic efficiency. It is also observed that the rate of inhibitor reaction decreases with the proportional addition of [MAA]. 
Optimized reaction conditions were utilized to measure the absorbance change $A_{t}(t=$ 15 and $20 \mathrm{~min})$ with varying [MAA] $\left(0.20 \times 10^{-5}\right.$ to $\left.3.0 \times 10^{-5}\right)$. The plot of At versus [MAA] exhibits a linear dependency (Figure 1). It can be served as a calibration curve for the MAA determination. The relevant expressions are given by equations 1 and 2 .

Reaction Condition: $\mathrm{pH}=4.0 \pm 0.02$, $[$ Pyrazine $]=7.5 \times 10^{-4} \mathrm{M}, \mathrm{I}=0.05 \mathrm{M}(\mathrm{KCl}),\left[\mathrm{Ru}(\mathrm{CN})_{6}{ }^{4}\right]=6.25 \times 10^{-5} \mathrm{M}$, Temperature $=45.0 \pm 0.1{ }^{\circ} \mathrm{C}$ and $\left[\mathrm{Hg}^{+2}\right]=8.5 \times 10^{-5} \mathrm{M}$.

$$
\begin{aligned}
& A_{15}=0.120-3.52 \times 10^{4}[\mathrm{MAA}] \\
& A_{20}=0.146-4.76 \times 10^{4}[\mathrm{MAA}]
\end{aligned}
$$

The standard deviation and linear regression coefficient for $\mathrm{A}_{15}$ and $\mathrm{A}_{20}$ versus [MAA] plots are $0.0026,0.0006$ and $0.9985,0.9967$, respectively. The reproducibility and accuracy of the present method for MAA determination were tested by dissolving the calculated amount of MAA in distilled water and performing experiments for recovery. The recovered MAA inclusive of percentage error and standard deviation are reported (Table 1). The observed detection limit for MAA was $2.0 \times 10^{-6} \mathrm{M}$.

The modified mechanistic scheme for inhibition, caused by sulfur donor ligand MAA to the mercury (II) catalyzed exchange of cyanide with pyrazine from hexacyanoruthenate(II) can be proposed by exploiting the same reaction without inhibitor and may schematically be represented by equations (3) - (7).

Table 1. Recovery results and \% error for MAA determination

\begin{tabular}{|c|c|c|c|c|}
\hline \multirow[b]{2}{*}{$\begin{array}{l}{[\text { MAA }] \times 10^{5} \mathrm{M}} \\
\text { (Taken) }\end{array}$} & \multicolumn{2}{|c|}{ A15 } & \multicolumn{2}{|c|}{$\begin{array}{r}A_{20} \\
\end{array}$} \\
\hline & $\begin{array}{c}{\left[\text { MAA] } \times 10^{5} \mathrm{M}\right.} \\
\text { (Found) }\end{array}$ & $\%$ Error & $\begin{array}{c}{\left[\text { MAA] } \times 10^{5} \mathrm{M}\right.} \\
\text { (Found) }\end{array}$ & $\%$ Error \\
\hline 0.25 & $0.26 \pm 0.016$ & +0.04 & $0.29 \pm 0.032$ & +0.16 \\
\hline 0.60 & $0.60 \pm 0.02$ & 0.000 & $0.60 \pm 0.00$ & 0.000 \\
\hline 1.10 & $1.05 \pm 0.06$ & -0.045 & $1.09 \pm 0.03$ & -0.009 \\
\hline 1.30 & $1.29 \pm 0.08$ & -0.008 & $1.33 \pm 0.04$ & +0.023 \\
\hline 1.75 & $1.75 \pm 0.00$ & \begin{tabular}{|l|}
0.000 \\
\end{tabular} & $1.73 \pm 0.06$ & -0.011 \\
\hline 2.25 & $2.21 \pm 0.05$ & -0.018 & $2.25 \pm 0.00$ & 0.000 \\
\hline 2.50 & $2.50 \pm 0.01$ & 0.000 & $2.55 \pm 0.08$ & +0.020 \\
\hline 2.90 & $2.92 \pm 0.08$ & +0.007 & $2.88 \pm 0.07$ & -0.007 \\
\hline
\end{tabular}

$$
\text { Reaction Condition: } \mathrm{pH}=4.0 \pm 0.02 \text {, [Pyrazine }]=7.5 \times 10^{-4} \mathrm{M}, \mathrm{I}=0.05 \mathrm{M}(\mathrm{KCl}),\left[\mathrm{Ru}(\mathrm{CN})_{6}^{4-}\right]=6.25 \times 10^{-5} \mathrm{M} \text {, }
$$

Since the inspected substitution reaction does not proceed without catalyst under specified reaction condition (not considered in the above scheme) [54], so the current $\mathrm{Hg}$ (II) catalyzed reaction system must produce more efficient and accurate results for the MAA determination. Considering " $\mathrm{S}_{\mathrm{o}}$ " as the initial concentration of $\left[\mathrm{Ru}(\mathrm{CN})_{6}{ }^{4-}\right]$ we can deduce the rate expression very similar to the enzyme-catalyzed reaction (in the presence of an inhibitor) for a single substrate. The catalyzed reaction rate $\left(\mathrm{V}_{\mathrm{o}}\right)$ in the absence of an inhibitor can be represented by Eq. (8).

$$
\mathrm{V}_{\mathrm{o}}=\frac{\mathrm{V}_{\max }}{1+\frac{\mathrm{K}_{\mathrm{m}}}{\left[\mathrm{S}_{\mathrm{o}}\right]}}
$$

Equation (8) can be rearranged in the form of Lineweaver-Burk expression [55] (Eq. 9). 


$$
\begin{aligned}
& {\left[\mathrm{Ru}(\mathrm{CN})_{6}\right]^{4-}+\quad \mathrm{Hg}^{2+}+\mathrm{H}_{2} \mathrm{O} \stackrel{\mathrm{K}}{\rightleftharpoons}\left[(\mathrm{CN})_{5} \mathrm{RuCN} \text {-------- }\left(\mathrm{Hg}^{2+}\right)-------\mathrm{H}_{2} \mathrm{O}\right]^{2-}} \\
& \begin{array}{c||l}
\text { - Inhibitor (I) } & \text { + Inhibitor (I) } \\
\mathrm{K}_{\mathrm{Cl}}^{\prime} & \mathrm{K}_{\mathrm{Cl}}
\end{array} \\
& \mathrm{Hgl}
\end{aligned}
$$

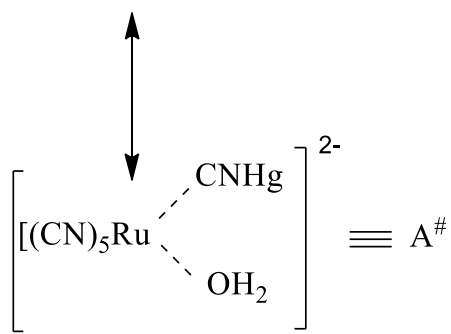

$$
\begin{aligned}
& -\mathrm{HgCN}^{+} \downarrow \mathrm{k}_{1} \text { (slow) } \\
& {\left[\mathrm{Ru}(\mathrm{CN})_{5} \mathrm{H}_{2} \mathrm{O}\right]^{3-}}
\end{aligned}
$$

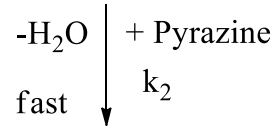

$$
\begin{aligned}
& {\left[\mathrm{Ru}(\mathrm{CN})_{5}-\text { Pyrazine }\right]^{3-}}
\end{aligned}
$$

$$
\mathrm{HgCN}^{+} \quad+\mathrm{H}^{+} \rightleftharpoons \mathrm{Hg}^{2+}+\mathrm{HCN}
$$

Scheme 1. The mechanistic pathway for the $\mathrm{Hg}$ (II) catalyzed exchange of cyanide with pyrazine from hexacyanoruthenate(II)

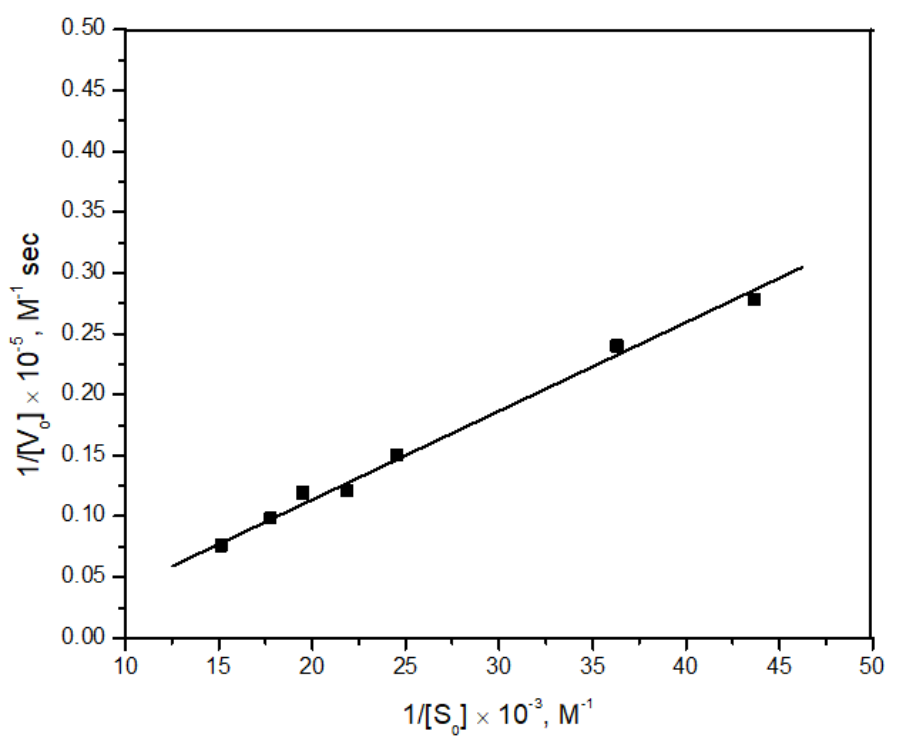

Figure 2. The Lineweaver-Burk plot for the determination of $\mathrm{K}_{\mathrm{m}}$ and $\mathrm{V}_{\max }$ in the absence of inhibitor. Reaction Condition: $\mathrm{pH}=4.0 \pm 0.02$, [Pyrazine $]=7.5 \times 10^{-4} \mathrm{M}$, Temperature $=45.0 \pm 0.1^{\circ} \mathrm{C}, \mathrm{I}=0.05 \mathrm{M}(\mathrm{KCl})$ and $\left[\mathrm{Hg}^{+2}\right]=8.5 \times 10^{-5} \mathrm{M}$.

$$
\frac{1}{V_{o}}=\frac{1}{V_{\max }}+\frac{\mathrm{K}_{\mathrm{m}}}{\mathrm{V}_{\max }} \frac{1}{\left[\mathrm{~S}_{\mathrm{o}}\right]}
$$

Here $\mathrm{K}_{\mathrm{m}}$ corresponds to M-M (Michaelis-Menten) constant; the maximum rate at larger substrate concentration is represented by $\mathrm{V}_{\max }$, and $\mathrm{V}_{\mathrm{o}}$ shows the initial reaction rate in the defection of inhibitor.

The plot of $1 / \mathrm{V}_{\mathrm{o}}$ versus $1 /\left[\mathrm{S}_{\mathrm{o}}\right]$ is in accordance with the equation of straight line having a slope and intercept of $\mathrm{K}_{\mathrm{m}} / \mathrm{V}_{\max }$ and $1 / \mathrm{V}_{\max }$, respectively (Figure 2). The calculated value of $\mathrm{K}_{\mathrm{m}}$ was found to be $0.188 \pm 0.015 \mathrm{mM}$. 
Equation (10) represents the initial reaction rate $\left(\mathrm{V}_{\mathrm{i}}\right)$ at constant catalyst concentration, in the presence of inhibitor (MAA).

$$
\begin{array}{r}
\mathrm{K}_{\mathrm{m}}^{\prime}=\mathrm{K}_{\mathrm{m}}\left(1+\frac{\left[\mathrm{I}_{\mathrm{o}}\right]}{\mathrm{K}_{\mathrm{Cl}}^{\prime}}\right) \\
\mathrm{V}_{\mathrm{i}}=\frac{\mathrm{V}_{\text {max }}}{1+\frac{\mathrm{K}_{\mathrm{m}}^{\prime}}{\left[\mathrm{S}_{\mathrm{o}}\right]}}
\end{array}
$$

Where $\mathrm{K}_{\mathrm{m}}^{\prime}$ represents the probable value of $\mathrm{M}-\mathrm{M}$ constant for the catalyzed reaction in the presence of inhibitor [56], $\mathrm{K}_{\mathrm{CI}}^{\prime}$ shows the dissociation constant of the catalyst inhibitor complex (C-I) and the initial inhibitor concentration is $\mathrm{I}_{\mathrm{o}}$.

$$
\mathrm{V}_{\mathrm{i}}=\frac{\mathrm{V}_{\mathrm{max}}}{1+\frac{\mathrm{K}_{\mathrm{m}}}{\left[\mathrm{S}_{\mathrm{o}}\right]}\left(1+\frac{\left[\mathrm{I}_{\mathrm{o}}\right]}{\mathrm{K}_{\mathrm{CI}}^{\prime}}\right)}
$$

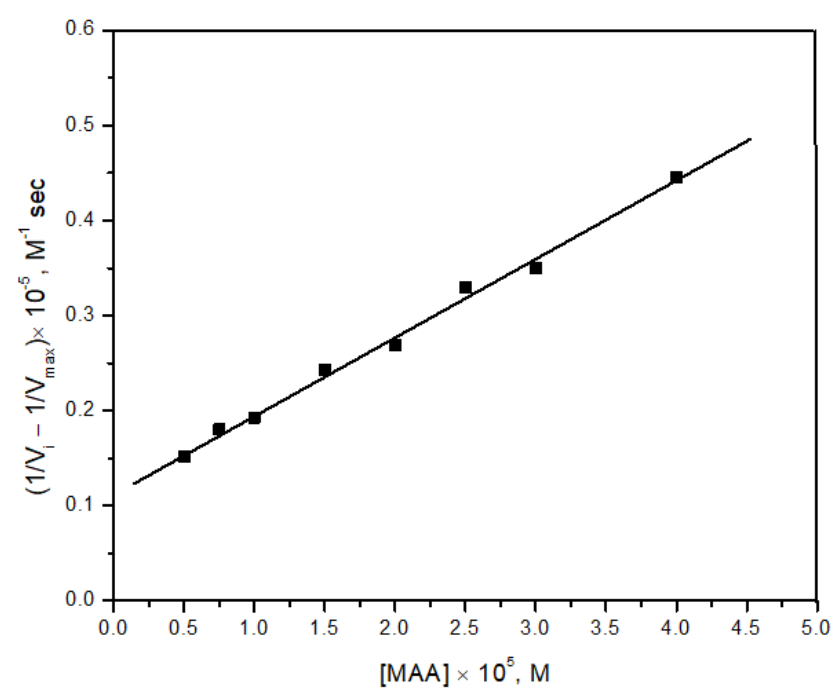

Figure 3. The plot of $\left(1 / \mathrm{V}_{\mathrm{i}}-1 / \mathrm{V}_{\max }\right)$ versus initial concentration of inhibitor for the determination of $\mathrm{K}_{\mathrm{m}}$ and $\mathrm{K}_{\mathrm{CI}}$ Reaction Condition: $\mathrm{pH}=4.0 \pm 0.02$, [Pyrazine $]=7.5 \times 10^{-4} \mathrm{M}, \mathrm{I}=0.05 \mathrm{M}(\mathrm{KCl}),\left[\mathrm{Ru}(\mathrm{CN})_{6}{ }^{4-}\right]=6.25 \times 10^{-5}$

$\mathrm{M}$, Temperature $=45.0 \pm 0.1^{\circ} \mathrm{C}$ and $\left[\mathrm{Hg}^{+2}\right]=8.5 \times 10^{-5} \mathrm{M}$.

The double reciprocal of the above equation gives Eq. (11), which is in accordance to the Lineweaver-Burk expression.

$$
\frac{1}{V_{i}}-\frac{1}{V_{\max }}=\frac{\mathrm{K}_{\mathrm{m}}}{\left[\mathrm{S}_{\mathrm{o}}\right] \mathrm{V}_{\max }}+\frac{\mathrm{K}_{\mathrm{m}}}{\left[\mathrm{S}_{\mathrm{o}}\right] \mathrm{V}_{\max }} \frac{\left[\mathrm{I}_{\mathrm{o}}\right]}{\mathrm{K}_{\mathrm{CI}}^{\prime}}
$$

Equation (12) rules out the formation of substrate inhibitor complex, while for good results, the inhibitor "I" and catalyst "C" must form a stable complex.

The linear plot of $\left(\frac{1}{V_{i}}-\frac{1}{V_{\max }}\right)$ versus the initial [MAA] is aligned with the equation of a straight line (Figure 3). The evaluated $K_{m}$ value, in the presence of inhibitor, is in good agreement with the previously computed $\mathrm{K}_{\mathrm{m}}$ value in the defection of inhibitor $(0.188 \pm 0.015$ $\mathrm{mM})$. The calculated dissociation constant value of C-I complex $\left(\mathrm{K}_{\mathrm{CI}}^{\prime}\right)$ using the slope of the plot was $1.425 \times 10^{-5} \pm 0.02$ indicates the high stability of C-I complex.

The influence of diverse anions, cations, and chelating ligands on the quantitative determination of MAA was studied using A15 calibration curve (Table 2). It is important to note that the chelating ligands, which can significantly interfere with the determination of MAA by forming a stable complex with $\mathrm{Hg}(\mathrm{II})$ are absent in the reaction system under 
investigation. On the other hand, the cations and anions which may complex with MAA and other reactants must also be absent.

Table 2. Effect of diverse ions on Mercaptoacetic acid determination Reaction Condition: $\mathrm{pH}=4.0 \pm 0.02$, $[$ Pyrazine $]=7.5 \times 10^{-4} \mathrm{M}, \mathrm{I}=0.05 \mathrm{M}(\mathrm{KCl}),\left[\mathrm{Ru}(\mathrm{CN})_{6}^{4-}\right]=6.25 \times 10^{-5} \mathrm{M}$, Temperature $=45.0 \pm 0.1{ }^{\circ} \mathrm{C}$ and $\left[\mathrm{Hg}^{+2}\right]=8.5 \times 10^{-5} \mathrm{M}$.

\begin{tabular}{l|c|c} 
External ion & [External ion] M, limit & Interference \\
\hline $\mathrm{NO}_{3}{ }^{-}$ & $2.0 \times 10^{-4}$ & Almost non interfering \\
\hline $\mathrm{I}^{-}$ & $6.0 \times 10^{-4}$ & No Interference \\
\hline $\mathrm{SO}_{4}^{2-}$ & $2.0 \times 10^{-4}$ & Interfering significantly \\
\hline $\mathrm{Na}^{+}$ & $6.0 \times 10^{-5}$ & Interfering appreciably \\
\hline $\mathrm{Pb}^{2+}$ & $4.0 \times 10^{-5}$ & No Interference \\
\hline $\mathrm{Cu}^{2+}$ & $2.0 \times 10^{-4}$ & No Interference \\
\hline $\mathrm{Cd}^{2+}$ & $8.0 \times 10^{-5}$ & No Interference \\
\hline $\mathrm{Mg}^{2+}$ & $6.0 \times 10^{-4}$ & No Interference \\
\hline $\mathrm{Zn}^{2+}$ & $2.0 \times 10^{-4}$ & No Interference \\
\hline $\mathrm{Fe}^{3+}$ & $8.0 \times 10^{-4}$ & No Interference \\
\hline $\mathrm{Al}^{3+}$ & $4.0 \times 10^{-4}$ & No Interference \\
\hline $\mathrm{C}_{2} \mathrm{O}{ }^{2-}$ & $4.0 \times 10^{-4}$ & Interfering significantly \\
\hline $\mathrm{HEDTA}$ & $8.0 \times 10^{-4}$ & Interfering significantly \\
\hline EDTA & $6.0 \times 10^{-4}$ & Interfering significantly \\
\hline DTPA & $6.0 \times 10^{-4}$ & Interfering significantly \\
\hline IDA & $8.0 \times 10^{-4}$ & Interfering significantly
\end{tabular}

\section{Conclusions}

A sensitive, rapid, and more accurate spectrophotometric method was developed to determine MAA at a micro-level. The present investigation, based on ligand exchange reaction between hexacyanoruthenate(II) and pyrazine catalyzed by $\mathrm{Hg}(\mathrm{II})$ is more useful as the uncatalyzed reaction is insignificant under specified reaction condition. The addition of inhibitor only retards the rate of catalyzed reaction, which eventually escalates the efficiency and accuracy of the present system for inhibitors determination. The proposed method provides the detection of MAA up to $2.0 \times 10^{-6} \mathrm{M}$ indicates that the methodology can be effectively and economically utilized to analyze the industrial and biological samples having MAA. This method can also be convincingly adopted for the quality check of MAA containing products.

\section{Funding}

This research received no external funding.

\section{Acknowledgments}

This research received no acknowledgment.

\section{Conflicts of Interest}

The authors declare no conflict of interest.

\section{References}

1. Tang, K. Chemical diversity and biochemical transformation of biogenic organic sulfur in the ocean. Front Mar Sci 2020, 7, https://doi.org/10.3389/fmars.2020.00068.

2. Abadie, C.; Tcherkez, G. Plant sulphur metabolism is stimulated by photorespiration. Communications Biology 2019, 2, https://doi.org/10.1038/s42003-019-0616-y. 
3. Kolluru, G.K.; Shen, X.; Kevil, C.G. Reactive sulfur species: a new redox player in cardiovascular pathophysiology. Arterioscler Thromb Vasc Biol 2020, 40, 874-884, https://doi.org/10.1161/ATVBAHA.120.314084.

4. Fukuto, J.M.; Ignarro, L.J.; Nagy, P.; Wink, D.A.; Kevil, C.G.; Feelisch, M.; Cortese-Krott, M.M.; Bianco, C.L.; Kumagai, Y.; Hobbs, A.J.; Lin, J.; Ida, T.; Akaike, T. Biological hydropersulfides and related polysulfides-a new concept and perspective in redox biology. FEBS Lett 2018, 592, 2140-2152, https://doi.org/10.1002/1873-3468.13090.

5. Shetty, P.; Shetty, A.N.; Gadag, R.V. Indirect complexometric determination of thallium(III) using thioglycolic acid as masking agent . Ind J Chem Tech 2000, 7, 227-229.

6. Platzer, S.; Kar, M.; Leyma, R.; Chib, S.; Roller, A.; Jirsa, F.; Krachler, R.; MacFarlane, D.R.; Kandioller, W.; Keppler, B.K. Task-specific thioglycolate ionic liquids for heavy metal extraction: Synthesis, extraction efficacies and recycling properties. $J$ of Hazard Mater 2017, 324(B), 241-249, https://doi.org/10.1016/j.jhazmat.2016.10.054.

7. Mir, I.M.; Lu, Q.; Xie, Y.; Zhu, L.; Wang, X. Detection of lead using thioglycolic acid capped ZnSe and ZnSe@ZnS core-shell quantum dots. IOP Conf. Series: Mater Sci Eng 2019, 490, https://doi.org/10.1088/1757-899X/490/2/022024.

8. Vijayaraghavan, R.; Vedaraman, N.; Muralidharan, C.; Mandal, A.B.; Macfarlane, D.R. Aqueous ionic liquid solutions as alternatives for sulphide-free leather processing. Green Chem 2015, 17, 1001-1007, https://doi.org/10.1039/c4gc01476f.

9. Xie, N.; Ding, X.; Wang, X.; Wang, P.; Zhao, S.; Wang, Z. Determination of thioglycolic acid in cosmetics by capillary electrophoresis, $J$ Pharm Biomed Anal 2014, 88, 509-512, https://doi.org/10.1016/j.jpba.2013.10.003.

10. Liu, Y.; Li, H.; Shu, W.; Chen, Q. Synthesis and application of antimony pent(isooctyl thioglycollate). $J$ Cent. South Univ. Technol 2005, 12, 64-67, https://doi.org/10.1007/s11771-005-0205-8.

11. Mousaa, I.M.; Radi, H. Comparative studies of anticorrosion performance of novel inhibitors based on oleic acid and sulfur/nitrogen containing compounds in UV-curable coatings. Corrosion Engineering, Science and Technology 2017, 52, 547-556, https://doi.org/10.1080/1478422X.2017.1355657.

12. Xia, L.; Hou, S.; Ren, X.; Wang, Z. Effects of thioglycolic acid on in vivo oocytes maturation in mice. PLoS ONE 2011, 6, https://doi.org/10.1371/journal.pone.0023996.

13. Gan, H.F.; Meng, X.S.; Song, C.C.; Li, B.X. A survey on health effects in a human population exposed to permanent-waving solution containing thioglycolic acid. J Occup Health 2003, 45, 400-404, https://doi.org/10.1539/joh.45.400.

14. Wang, L.H.; Chen, Z.S. Determination of thioglycolic acid and cysteine in hair-treatment products at ceramic carbon composite electrodes. Electroanalysis 1997, 9, 1294-1297, https://doi.org/10.1002/elan.1140091616.

15. Cavrini, V.; Andrisano, V.; Scapini, G. HPLC determination of thioglycolic acid and other aliphatic thiols in cosmetic formulations using ethacrynic acid as precolumn derivatization reagent. Int J Cosmet Sci 1990, 12, 141-150, https://doi.org/10.1111/j.1467-2494.1990.tb00530.x.

16. Huang, Y.; Lin, T.; Hou, L.; Ye, F.; Zhao, S. Colorimetric detection of thioglycolic acid based on the enhanced $\mathrm{Fe}^{3+}$ ions Fenton reaction. Microchem J 2019, 144, 190-194, https://doi.org/10.1016/j.microc.2018.09.003.

17. Dedov, A.G.; Marchenko, D.Y.; Zrelova, L.V.; Ivanova, E.A.; Sandzhieva, D.A.; Parkhomenko, A.A.; Budinov, S.V.; Lobakova, E.S.; Dol'nikova, G.A. new method for determination of total of organic sulfur compounds in hydrocarbon media. Pet Chem 2018, 58, 714-720, https://doi.org/10.1134/S0965544118080030.

18. Kostara, A.; Tsogas, G.Z.; Vlessidis, A.G.; Giokas, D.L. Generic assay of sulfur-containing compounds based on kinetics inhibition of gold nanoparticle photochemical growth. ACS Omega 2018, 3, 16831-16838, https://doi.org/10.1021/acsomega.8b02804.

19. Raab, A.; Feldmann, J. Biological sulphur-containing compounds - Analytical challenges. Anal Chim Acta 2019, 1079, 20-29, https://doi.org/10.1016/j.aca.2019.05.064.

20. Zhand, S.; Jiang, J.Q. Detection of imidacloprid and Bisphenol-S by Solid Phase Extraction (SPE) coupled with UV-VIS spectrometer and LC-MS. Biointerface Res Appl Chem 2019, 9, 4433-4438. https://doi.org/10.33263/BRIAC95.433438

21. Zhang, Z.; Baeyens, W.R.G. ; Zhang, X.; Zhao, Y.; Van-Der-Weken, G. Chemiluminescence detection coupled to liquid chromatography for the determination of penicillamine in human urine. Anal Chim Acta 1997, 347, 325-332, https://doi.org/10.1016/S0003-2670(97)00171-2.

22. Cao, L.; Wei, T.; Shi, Y.; Tan, X.; Meng, J. Determination of D-penicillamine and tiopronin in human urine and serum by HPLC-FLD and CE-LIF with 1,3,5,7-tetramethyl-8-bromomethyl-difluoroboradiaza-sindacene. J Liq Chrom Relat Tech 2018, 41, 58-65, https://doi.org/10.1080/10826076.2017.1348953.

23. Dzieko, U.; Kubczak, N.; Przybylska, K.P.; Patalski, P.; Balcerek, M. Development of the method for determination of volatile sulfur compounds (vscs) in fruit brandy with the use of HS-SPME/GC-MS. Molecules 2020, 25, https://doi.org/10.3390/molecules25051232. 
24. Feng, G.; Sun, S.; Wang, M.; Zhao, Q.; Liu, L.; Hashi, Y.; Jia, R. Determination of four volatile organic sulfur compounds by automated headspace technique coupled with gas chromatography-mass spectrometry. J Water Supply Res T 2018, 67, 498-505, https://doi.org/10.2166/aqua.2018.011.

25. Perez-Ruiz, T.; Martinez- Lozano, C.; Tomas, V.; Sidrach-de-cardona, C. Flow-injection fluorimetric determination of penicillamine and tiopronin in pharmaceutical preparations. J Pharm Biomed Anal 1996, 15, 33-38, https://doi.org/10.1016/0731-7085(96)01821-3.

26. Al-Majed, A.A. Specific spectrofluorometric quantification of d-penicillamine in bulk and dosage forms after derivatization with 4-fluoro-7-nitrobenzo-2-oxa-1,3-diazole. Anal Chim Acta 2000, 408, 169-175, https://doi.org/10.1016/S0003-2670(99)00869-7.

27. Raoof, J.B.; Ojani, R.; Majidian, M.; Chekin, F. Voltammetric determination of D-penicillamine based on its homogeneous electrocatalytic oxidation with potassium iodide at the surface of glassy carbon electrode. Russ J Electrochem 2010, 46, 1395-1401, https://doi.org/10.1134/S1023193510120098.

28. Raoof, J.B.; Ojani, R.; Amiri-Aref, M. Catechol as an electrochemical indicator forvoltammetric determination of $D$-penicillamine in aqueous media at the surface of carbonpaste electrode. Russ $J$ Electrochem 2012, 48, 450-456, https://doi.org/10.1134/S102319351204012X.

29. Shoba, S.; Bankole, O.M.; Ogunlaja, A.S. Electrochemical determination of trace sulfur containing compounds in model fuel based on a silver/polyaniline-modified electrode. Anal Methods 2020, 12, 10941106, https://doi.org/10.1039/C9AY02382H.

30. Martinović, A.; Radić, N. Kinetic potentiometric determination of penicillamine and N-acetyl-L-cysteine based on reaction with iodate. Acta Chim Slovenica 2009, 56, 503-506.

31. Nelson, J. Nuclear magnetic resonance spectroscopic method for determination of penicillamine in capsules. J Assoc Off Anal Chem 1981, 64, 1174-1178, https://doi.org/10.1093/jaoac/64.5.1174.

32. Issopoulos, P.B.; Salta, S.E. High-sensitive spectrophotometric determination of micro molar concentrations of D-penicellamine by means of a coupled redox-complexation reaction, II Farmaco 1997, 52, 113-118, https://doi.org/10.1002/chin.199735321.

33. Ni, L.; Geng, X.; Li, S.; Ning, H.; Guan, Y. A flame photometric detector with a silicon photodiode assembly for sulfur detection. Talanta 2020, 207, https://doi.org/10.1016/j.talanta.2019.120283.

34. Naik, R.M.; Agarwal, A.; Prasad, S.; Verma, A.K. Trace determination of thiosulphate and thioglycolic acid using novel inhibitory kinetic spectrophotometric method. Microchem $J$ 2009, 93, 43-48, https://doi.org/10.1016/j.microc.2009.04.006.

35. Prasad, S. Kinetic determination of organosulphur ligands by inhibition: Trace determination of cysteine and

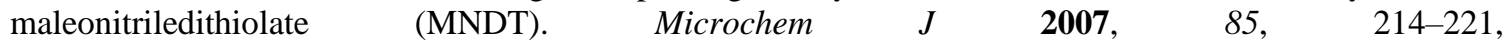
https://doi.org/10.1016/j.microc.2006.05.011.

36. Naik, R.M.; Prasad, S.; Kumar, B.; Yadav, S.B.; Asthana, A.; Yoshida, M. Ligand substitution kinetic assay of antitubercular drug isoniazid in pure and pharmaceuticals formulations. Microchem J 2013, 111, 108-115, https://doi.org/10.1016/j.microc.2013.02.011.

37. Skowron, M.; Ciesielski, W. Spectrophotometric determination of methimazole, Dpenicillamine, captopril, and disulfiram in pure form and drug formulations. $J$ Anal Chem 2011, 66, 714-719, https://doi.org/10.1134/S1061934811080132.

38. Naik, R.M.; Prasad, S.; Kumar. B.; Chand, V. Kinetic assay of D-penicillamine in pure and pharmaceutical formulations based on ligand substitution reaction. Microchem $J$ 2013, 111, 97-102, https://doi.org/10.1016/j.microc.2012.07.015.

39. Agarwal, A.; Prasad, S.; Naik, R.M. Inhibitory kinetic spectrophotometric method for the quantitative estimation of D-penicillamine at micro levels. Microchem $J$ 2016, 128, 181-186, https://doi.org/10.1016/j.microc.2016.04.005.

40. Srivastava, A.; Sharma, V.; Prajapati, A,; Srivastava, N.; Naik, R.M. Spectrophotometric determination of ruthenium utilizing its catalytic activity on oxidation of hexacyanoferrate(II) by periodate ion in water samples. Chem Chem Technol 2019, 13, 275-279, https://doi.org/10.23939/chcht13.03.275.

41. Gomes-Junior, F.A.; Silva, R.S.; Lima, R.G.; Vannier-Santos, M.A. Antifungal mechanism of [RuIII(NH3)4catechol] ${ }^{+}$complex on fluconazole-resistant Candida tropicalis. FEMS Microbio Lett 2017, 364, https://doi.org/10.1093/femsle/fnx073.

42. Athar, F.; Husain, K.; Abid, M.; Azam, A. Synthesis and anti-amoebic activity of gold(I), ruthenium(II), and copper(II) complexes of metronidazole. Chem Biodiversity 2005, 2, 1320-1330, htpps://dio.org/10.1002/cbdv.200590104.

43. Coverdale, J.P.C.; Carron, T.L.M.; Canelon, I.R. Designing ruthenium anticancer drugs: what have we learnt from the key drug candidates? Inorganics 2019, 7, https://doi.org/10.3390/inorganics7030031.

44. Gua, L.; Lia. X.; Ran. Q.; Kang, C.; Lee, C.; Shen, J. Antimetastatic activity of novel ruthenium (III) pyridine complexes. Cancer Med 2016, 5, 2850-2860, https://doi.org/10.1002/cam4.826.

45. Bastos, C.M.; Gordon, K.A.; Ocain, T.D. Synthesis and immunosuppressive activity of ruthenium complexes. Bioorg Med Chem Lett 1998, 8, 147-150, https://doi.org/10.1016/s0960-894x(97)10205-0.

46. Kenny, R.G.; Marmion, C.J. Toward multi-targeted platinum and ruthenium drugs-A new paradigm in cancer drug treatment regimens? Chem Rev 2019, 119, 1058-1137. https://doi.org/10.1021/acs.chemrev.8b00271. 
47. De Grandis, R.A.; Santos, P.W.D.S.D.; Oliveira, K.M.; Machoado, A.R.T.; Aissa, A.F.; Batista, A.A.; Autunes, L.M.G.; Pavan, F.R. Novel lawsone-containing ruthenium(II) complexes: Synthesis, characterization and anticancer activity on 2D and 3D spheroid models of prostate cancer cells. Bioorg Chem 2019, 85, 455-468, https://doi.org/10.1016/j.bioorg.2019.02.010.

48. Lin, K.; Zhao, Z.Z.; Bo, H.B.; Hao, X.J.; Wang, J.Q. Applications of ruthenium complex in tumor diagnosis and therapy. Pharmacol 2018, 9, https://doi.org/10.3389/fphar.2018.01323.

49. Zhang, Y.; Uahengo, V.; Cai, P.; Cheng, G.D. Synthesis, characterization, and antitumor activity of mononuclear and dinuclear ruthenium complexes. J Cord Chem 2018, 71, 2091-2101, https://doi.org/10.1080/00958972.2018.1469749.

50. Yu, B.; Rees, T.W.; Liang, J.; Jin, C.; Chen, Y.; Ji, L.; Chao, H. DNA interaction of ruthenium(II) complexes with imidazo $[4,5-f][1,10]$ phenanthroline derivatives. Dalton Trans 2019, 48, 3914-21, https://doi.org/10.1039/C9DT00454H.

51. Simovic, A.; Masnikosa, R.; Bratsos, I.; Alessio, E. Chemistry and reactivity of ruthenium(II) complexes: DNA/protein binding mode and anticancer activity are related to the complex structure. Coord Chem Rev 2019, 398, https://doi.org/10.1016/j.ccr.2019.07.008.

52. Rastogi, R.; Srivastava, A.; Naik, R.M. Kinetic and mechanistic analysis of ligand substitution of aquapentacyanoruthenate(II) in micelle medium by nitrogen donor heterocyclic ligand. J Disp Sc Tech 2019, 1, https://doi.org/10.1080/01932691.2019.1614042.

53. Srivastava, A.; Naik, R.M.; Rastogi, R. Spectrophotometric kinetic study of mercury(II) catalyzed formation of $\left[4-\mathrm{CN}-\mathrm{PyRu}(\mathrm{CN})_{5}\right]^{3-}$ via ligand exchange reaction of hexacyanoruthenate(II) with 4-cyanopyridine - a mechanistic approach. J Iran Chem Soc 2020, https://doi.org/10.1007/s13738-020-01927-w.

54. Naik, R.M.; Singh, P.K.; Rastogi, R.; Singh, R.; Agarwal, A. Kinetic-catalytic and spectrophotometric determination of $\mathrm{Hg}$ (II) using its catalytic effect on ligand substitution reaction between hexacyanoferrate(II) and pyrazine. Annali di Chimica 2007, 97, 1169-1179, https://doi.org/10.1002/adic.200790103.

55. Lineweaver, H.; Burk, D. The determination of enzyme dissociation constants. J Am Chem Soc 1934, 156, 658-666, https://doi.org/10.1021/ja01318a036.

56. Tinoco, I.; Sauer, K.; Wang, J.C. Physical chemistry, Principles and applications in biological sciences. Prentice-Hall Inc., New Jersey, USA, 1978; pp. 351 